\title{
Developing Oral Communication Skills through Collaborative Learning: Implications for Nigerian Teachers
}

\author{
Muhammad Mukhtar Aliyu
}

Department of English, Faculty of Arts and Education, Bauchi State University, Gadau, Bauchi State, Nigeria

\begin{abstract}
Considering the need for effective oral communication skills in academic and professional successes, this paper reviews oral communication skills and collaborative learning. It highlights some benefits of collaborative learning. Specifically, it discusses how to develop students' oral communication skills through collaborative learning. Finally, the paper suggests that empirical studies should be conducted to provide teachers with methods that would allow students to collaborate in the learning process in order develop their oral communication skills. It also gives some pedagogical implications for teachers.
\end{abstract}

Keywords- Collaborative learning, Nigeria, oral communication skills.

\section{INTRODUCTION}

Oral communication skills which include speaking and listening (Ogunsiji, 2004) are indispensable life skills. These skills have been used to communicate ideas long before the development of a writing system. Ability to master and use the skills effectively influences one's level of success in different life endeavours, particularly in the current era of globalisation. Therefore, the place of listening and speaking in teaching any language cannot be overemphasised since the goal is to enhance effective communication. However, acquiring these important skills poses many challenges to learners especially when learning a second (L2) or foreign language (FL). In Nigeria for instance, English is used as the official language and it has been a compulsory course in Nigerian educational institution for decades. The role the English language plays in the country necessitates the need for Nigerian students to be proficient in their oral communication in the language: speaking, listening. However, there have been complaints from teachers, parents and government on the Nigerian students' inability to communicate effectively using correct English expressions in their speaking.

Various factors hinder the students from developing their oral communication skills in English which include insufficient teaching hours for English, unskilled teachers, students' poor proficiency, non-English speaking environment (Chang \& Goswami, 2011; Chen \& Goh, 2011), large class sizes, insufficient facilities and equipment (Aduwa-Ogiegbaen \& Iyamu, 2006), teaching approach and inadequate emphasis on speaking in the classroom.

The concern of this paper is on the teaching approaches adopted by Nigerian teachers in teaching oral communication skills. From experience, most of the teaching methods adopted by teachers in Nigeria do not give adequate emphasis on developing the students' oral communication skills. They mostly dominate the classes and hardly give the students opportunity to speak or interact in the learning process. This hinders the development of the students' oral communication skills because one cannot learn to speak through listening only but through the practice of speaking (Derakhshan, Tahery, \& Mirarab, 2015). As for the listening skills, only a few students pay much attention to what the teacher says while teaching because they know they would not be asked to participate or contribute based on what the teachers said.

From the general observation of teaching of English Language in Nigeria, there is almost a complete neglect of listening and speaking skills from primary to the tertiary levels of education. Students are not given enough opportunities to practice oral expression or listening comprehension in their classrooms. This hinders them from becoming competent communicators. In comparison with reading and writing skills, in most Nigerian educational institutions, reading and writing are taught as courses on their own but in many cases, no course is assigned specifically for the teaching of speaking or listening skills. Speaking and listening skills are only learned while learning other courses. Even in rare cases where a course is assigned for the teaching of speaking and listening skills, students are only told about the skills, about how to become effective listeners or speakers. They are not taught the actual speaking or listening. They are not engaged in the process or allowed to practice the actual speaking or listening in the classroom.

These are some of the challenges faced by Nigerian students in acquiring speaking and listening skills. Therefore, this paper suggests that collaborative learning 
could be employed in teaching all subjects to allow the students to develop their oral communication skills because it creates a context where all students can be engaged and use the language in the learning process. Alternatively, this paper also recommends that there is a need for the introduction of courses specifically for the teaching speaking and listening skills.

\section{ORAL COMMUNICATION SKILLS}

Oral communication skills comprise listening and speaking skills (Ogunsiji, 2004). They are described as the most important language skills because they are the commonest channels through which most people encounter language and learn to use and interpret feelings or messages (Johnstone and Milne 1995). They always go hand-in-hand, since one is dependent on the other for effective communication in most cases. It is asserted that listening takes about $40-50 \%$; speaking, $25-30 \%$ of the total time one spends on communication. On the other hand, reading takes only 11-16\%; and writing, about 9\% (Gilakjani and Ahmadi, 2011). Thus, effective communication consists of the ability to produce well-articulated speech, as well as ability to receive (listen).

Despite the importance of speaking in an educational setting, many students experience a feeling of uneasiness and anxiety when having to speak in a second or foreign language (Suleimenova, 2013). Nigerian students are also no exception. Many Nigerian students feel nervous to speak English to teachers and peers for fear of being mocked should they commit errors of grammar or pronunciation (Taiwo, 2013). Another factor that affects the students' spoken English is the excessive use of mother tongue inand outside the classrooms (Oyinloye, 2002).

In addition, most of the English textbooks emphasise more on written English than the spoken one which makes students memorise vocabulary instead of developing speaking skills (Taiwo, 2013). These factors hinder the development of the students' oral communication skills. To develop oral communication skills, students need to participate in the classroom's oral tasks (Derakhshan, Tahery, \& Mirarab, 2015). Therefore, this paper suggests that adopting collaborative learning method may help the students to develop their oral communication skills. For instance, it would allow the students to overcome their speaking anxiety and nervousness since the interaction is among peers. In addition, it would help teachers to manage their large class and give effective feedback since the students are grouped into smaller groups.
III. COLLABORATIVE LEARNING IN SECOND L2 LEARNING

Collaborative learning is described as an instructional methodology that uses a small group of students or pair in classroom activities (Storch, 2002). It provides opportunities for students to develop skills that are needed in today's world through group interactions while working with others (Imel, 1989; Kerka, 1990). In the learning process, learners are expected to act as resources for each other within a group. From the literature, collaborative learning has been supported theoretically and pedagogically by various studies. Theoretically, collaborative learning is based on social constructivism of Vygotsky (1978) who suggests that human development is inherently a socially situated activity. According to Vygotsky, a novice child's cognitive development arises in social interaction with a more able member of society. The more able member who may be an expert provides the novice with the appropriate level of assistance, which stretches the novice beyond his/her current level towards their potential level of development.

From the pedagogical perspectives, collaborative learning has been supported by the communicative approach to second language instruction and its emphasis on providing learners with opportunities to use the L2. Therefore, based on these perspectives, learners should be encouraged to participate in activities which foster interaction and coconstruction of knowledge

Various researchers have identified numerous benefits of collaborative learning which include developing social skills, psychological skills, critical thinking skills and academic achievement (Laal \& Ghodsi, 2012). Collaborative learning also fosters the development of interpersonal relationships and reduces anxiety. It develops oral communication skills (Yager, Johnson, \& Johnson, 1985). It promotes mutual interaction, negotiations and sharing of expertise among learners (Yong, 2010). Lastly, it prepares students for the challenges in the workplace, where collaborative activities and problem-solving are key elements of many careers.

In the current educational system in Nigeria, competition is valued over cooperation. Students always compete with one another instead of cooperating with one another to achieve success. By incorporating collaborative learning method in teaching, the students may develop their oral communication skills. Sharing and exchanging ideas among peers might be easier since they are familiar to one another. When students are working in pairs or in small groups, one partner verbalises his/her answers while the other listens; ask questions or comments based on what he/she has heard. Clarification and explanation of one's answer is a very important part of the collaborative process and represents a higher-order thinking skill. As students work in groups and 
express themselves orally, they might minimise their anxiety and become fluent speakers. Teachers might also find it easier to control large classes and to monitor the students' learning process. It may also allow them to give feedback to the students' learning.

\section{CONCLUSION AND RECOMMENDATIONS}

This paper highlights the benefits of collaborative learning which include developing students' oral communication skills, social skills and academic skills. The paper also stresses the need to adopt collaborative learning method in our classrooms in order to develop students' oral communication skills. Therefore, the following are some recommendations for teachers and researchers:

- Researchers should conduct empirical studies to investigate the effectiveness of collaborative learning in developing oral communication skills

- The students should be assigned to work in pairs or smaller groups to help one another in- or outside their classrooms. Alternatively,

- Teachers should engage the students and give them enough opportunity to actively participate in the classroom

- Teachers should probe the students and make every student contribute during the group discussions through asking open-ended questions.

\section{REFERENCES}

[1] Aduwa-Ogiegbaen, S., \& Iyamu, E. (2006). Factors affecting quality of English language teaching and learning in secondary schools in Nigeria. College Student Journal, 40(3), 495-504.

[2] Austin, J. E. (2000). Principles for partnership. Journal of Leader to Leader. 18, 44-50.

[3] Bloom, B. S. (Ed.) (1956). Taxonomy of educational objectives. Handbook 1: Cognitive domain. White Plains, NY: Longman.

[4] Bruner, J. (1985). Vygotsky: A historical and conceptual perspective. In J. V. Wetsch (Ed.), Culture, communication, and cognition: Vygotskian perspectives (pp. 21-34). London: Cambridge University Press.

[5] Chang, M., \& Goswami, J. S. (2011). Factors affecting the implementation of communicative language teaching in Taiwanese college English classes. English Language Teaching, 4(2), 3-12.

[6] Chen, Z., \& Goh, C. (2011). Teaching oral English in higher education: Challenges to EFL teachers. Teaching in Higher Education, 16(3), 333-345.

[7] Derakhshan, A., Tahery, F., \& Mirarab, N. (2015). Helping adult and young learners to communicate in speaking classes with confidence. Mediterranean Journal of Social Sciences, 6(2), 520-525.
[8] Dewey, J. (2009). Democracy and education: An introduction to the philosophy of education. New York: Cosimo Classics.

[9] Ezeanyanike, P. A. (2013). Assessing benefits of collaborative learning environment for quality higher education in Nigeria. Journal of Educational and Social Research, 3(6), 85-94.

[10] Gilakjani, A.P. \& Ahmadi, M. R. (2011). A Study of Factors Affecting EFL Learners' English Listening Comprehension and the Strategies for Improvement. Journal of Language Teaching and Research, 2(5) 977-988.

[11]Laal, M. \& Ghodsi, S. M. (2012). Benefits of collaborative learning. Procedia - Social and Behavioral Sciences 31 (2012) 486 - 490.

[12]Leonard, P. E., \& Leonard, L.J. (2001). The collaborative prescription: Remedy or reverie? International Journal of Leadership in Education, 4(4), 383-99.

[13]Lubega, S. 1987. Cultivating effective listening and speaking skills. In Adegbija, E. (Ed)

[14]Effective study skills and use of English. Ilorin: The General Studies and General Awareness Division, University of Ilorin. 174-197.

[15] Maduekwe, A.N. 2007. Principles and practice of teaching English as a second language. Lagos: Vitaman Educational Books.

[16] Mayer, R. E. (2004). Should there be a three strikes rule against pure discovery? The case for guided methods of instruction. American Psychologist, 59(1), 14-19.

[17] McDonough, J., \& Shaw, C. (2003). Materials and Methods in ELT: A Teacher's Guide (2 ${ }^{\text {nd }}$ ed.). Oxford: Blackwell Publishing.

[18] Neo, M., \& Neo, T.-K. (2009). Engaging students in multimedia-mediated constructivist learning: Students' perceptions. Educational Technology and Society, 12(2), 254-266.

[19] Ogunsiji, A. (2004). Developing the basic language skills for communicative competence in learners of English as a second language. IBADAN Journal of English Studies, (1),19-34.

[20] Olanrewaju, A. T. (2016). Developing learners' communicative language skills in English as panacea for unemployment in Nigeria. International Journal of English Language, Literature and Humanities, iv (v), 26-37.

[21] Panitz, T. (1999). Benefits of Cooperative Learning in Relation to Student Motivation", in Theall, M. (Ed.) Motivation from within: Approaches for encouraging faculty and students to excel, New directions for teaching and learning. San Francisco, CA; USA. Josey-Bass publishing. 
[22] Panitz, T. (1996). A Definition of collaborative vs cooperative learning. Deliberations, London Metropolitan University; UK., Retrieved 5 Nov. 2011, from:

http://www.londonmet.ac.uk/deliberations/collaborativ e-learning/panitz-paper.cfm.

[23] Panitz, T. \& Panitz, P. (1996). Assessing students and yourself using the one minute paper and observing students working cooperatively. Cooperative Learning and College

TeachingNewsletter,6(3),Retrieved,5,Nov,2011,from: http://home.capecod.net/ tpanitz/tedsarticles/Assessm ent.htm.

[24] Slavin, R. E. (1989). Research on cooperative learning: An international perspective. Scandinavian Journal of Educational Research, 33(4), 231-243.

[25] Storch N (2005). Collaborative writing: product, process, and students' reflections. Journal for Second Language Writing 14(3), 153-73.

[26] Suleimenova, Z. (2013). Speaking anxiety in a foreign language classroom in Kazakhstan. Proceedings of 3rd World Conference on Learning, Teaching and Educational Leadership Procedia - Social and Behavioral Sciences 93 (2013), 1860 -1868.

[27] Totten, S., Sills, T., Digby, A., \& Russ, P. (1991). Cooperative learning: A guide to research. New York: Garland.

[28] Taiwo, F. (2013). An appraisal of spoken English language in Nigeria. Global Journal of Curriculum Studies and Instruction. Vol. 1 (1), 054-059.

[29] Vygotsky, L. (1980). Mind in society: The development of higher psychological processes. Cambridge, MA: Harvard University Press.

[30] Yager, S., Johnson, D.W. \& Johnson, R.T. (1985). Oral discussion groups-to-individual transfer, and achievement in cooperative learning groups. Journal of Educational Psychology, 77(1), 60-66. 